\title{
Economic Impact from Unrestricted Spread of Potato Cyst Nematodes in Australia
}

\author{
M. Hodda and D. C. Cook \\ First and second authors: CSIRO Entomology, GPO Box 1700, Canberra, ACT 2601, Australia; second author: CRC for National Plant \\ Biosecurity and Fenner School of Environment and Society, The Australian National University. \\ Accepted for publication 22 June 2009.
}

\section{ABSTRACT}

Hodda, M., and Cook, D. C. 2009. Economic impact from unrestricted spread of potato cyst nematodes in Australia. Phytopathology 99:13871393.

Potato cyst nematodes (PCN) (Globodera spp.) are quarantine pests with serious potential economic consequences. Recent new detections in Australia, Canada, and the United States have focussed attention on the consequences of spread and economic justifications for alternative responses. Here, a full assessment of the economic impact of PCN spread from a small initial incursion is presented. Models linking spread, population growth, and economic impact are combined to estimate costs of spread without restriction in Australia. Because the characteristics of the Australian PCN populations are currently unknown, the known ranges of parameters were used to obtain cost scenarios, an approach which makes the model predictions applicable generally. Our analysis indicates that mean annual costs associated with spread of PCN would increase rapidly initially, associated with increased testing. Costs would then increase more slowly to peak at over AUD $\$ 20$ million per year $\approx 10$ years into the future. Afterward, this annual cost would decrease slightly due to discounting factors. Mean annual costs over 20 years were $\$ 18.7$ million, with a 90\% confidence interval between AUD $\$ 11.9$ million and AUD\$27.0 million. Thus, cumulative losses to Australian agriculture over 20 years may exceed $\$ 370$ million without action to prevent spread of PCN and entry to new areas.

Additional keywords: cut flowers, export, Globodera rostochiensis, tomato, Victoria.
Potato cyst nematodes $(\mathrm{PCN})$ are some of the most damaging pests of potato crops, causing almost total crop failure at high abundances. Two species are now recognized, Globodera rostochiensis and G. pallida, which differ genetically, in environmental optima, and in host interactions. There are also strains or pathotypes within each species which differ in virulence, genetics, and responses to different hosts.

Both species are thought to have originated with the potato in South America. It has taken some time since cultivated potato plants began to be exported from South America in approximately 1600 , but PCN have now been distributed to many parts of the world (10). However, they are also absent from many areas (12). This pattern of distribution, combined with their economic impact, means that PCN are nematodes of the highest biosecurity and quarantine concern, their movement being regulated by over 100 countries (52).

In the European Union, PCN have been known in many countries for many years, and they are generally considered well established (91). Long-standing directives regulating testing for PCN and movement of potato plants have changed recently, which has heightened interest in the economic consequences of managing PCN in particular ways $(26,27)$. In parts of the United States and Canada, PCN were detected recently in areas previously free of these nematodes $(19,39,86)$. Other recent examples of spread include Indonesia ( $G$. rostochiensis) and Ukraine (G. rostochiensis from 1963 and G. pallida more recently) (50,65, 66,73 ). These detections have focussed attention on strategies for dealing with new outbreaks of PCN and their economic justifi-

Corresponding author: M. Hodda; E-mail address: mike.hodda@csiro.au

doi:10.1094/PHYTO-99-12-1387

(C) 2009 The American Phytopathological Society cation. The same issues arose in New Zealand, where PCN were introduced before 1972 (55). Two more recent incursions of PCN into Australia also raised similar issues regarding the benefits and costs of various potential strategies to deal with the problem $(55,85)$

The incursions into Australia were detected near Perth in 1986 $(82,83)$, and near Melbourne in $1991(38,44,45)$. Both incursions have involved only $G$. rostochiensis as far as is known (74). Following severe quarantine restrictions, the outbreak near Perth seems to have been restricted to the extent that proof that the state is a pest-free area is now being sought (Western Australian Minister for Agriculture, personal communication). The population near Melbourne has, however, continued to spread from the site of initial detection (34). This has occurred despite requirements for PCN testing, along with regulation of where and how potato can be grown and moved. Recently, there was a further expansion of the area in Victoria where PCN has been found (Victorian Department of Primary Industries, personal communication). This has led to interest in whether continued attempts at containment are the best response or whether other options are more beneficial economically $(43,48)$. The Australian potato industry is worth AUD\$500 million annually (4).

This article presents economic analyses of the costs of PCN to Australia if spread is unrestricted. The costs of the various options are estimated using many simulations to account for a range of possibilities because there is still considerable uncertainty over the biology under local conditions of the Victorian population of PCN, which seems genetically distinct from other populations (74). In the absence of specific data on local populations, known ranges of values have been used for biological parameters, which means that the model may have wide applicability and the results may be indicative of possible outcomes in other situations. Even so, eradication may be the most beneficial option both economically and ecologically. 


\section{MATERIALS AND METHODS}

Economic analysis used the model outlined by Cook and Matheson (17). The model is a stochastic simulation model using random number generators to simulate random events. This approach is common in risk analyses modeling natural systems with high parameter uncertainty and variability $(17,18)$. Parameters are stated within the model as probability distributions rather than point estimates and a Monte Carlo algorithm used to sample from each of these distributions (17).

A considerable number of parameters are used to estimate the ecological processes of spread, establishment, population growth, and crop damage, together with their economic consequences in terms of crop yields, testing for PCN, and control measures (Table 1). Each parameter is given a mean or modal value as well as variation about this value, which may have a number of statistical distributions as listed. The bases of the parameter estimates are described below.

In total, 5,000 iterations of the model were used. In each iteration, one value was randomly sampled across the range of each distribution. The model used Markov chains to estimate transitional probabilities between time periods (42). The time period used was 1 year, and all rates and probabilities quoted are per annum unless otherwise stated. The model was run over 20 years. All costs are in Australian Dollars at 2008 values.

A discount rate of $8 \%$ was used in the analysis, consisting of a margin of $3 \%$ on top of a real risk-free rate of $5 \%(16,22)$. The discount rate is a factor that translates expected benefits or costs in any given future year into present-value terms. It is based on the money from a benefit earned presently and invested being worth $8 \%$ more in a year's time due to inflation plus investment returns. Hence, to make the values equal, a future benefit is reduced or discounted by $8 \%$ per year. This is also known as opportunity cost.

Probability of spread. Probabilities of entry $\left(P_{\text {ent }}\right)$ and establishment $\left(P_{e s t}\right)$ are combined to give the probability of invasion outside the current area of distribution $\left(P_{i}\right)$ by equation 1 :

$$
P_{e n t}=P_{e n t} \times P_{e s t}, \text { where } 0<P_{i}<1
$$

In the absence of containment and mitigation measures, the probabilities of entry and establishment in new areas beyond the current distribution were both regarded as high: within the range 0.7 to 1.0 (8). G. rostochiensis cysts can be transported by contaminated seed, farm machinery, livestock, farm workers, transport of soil, contaminated root crops, stock feed or nursery stock, water runoff, or wind (89). Cysts are extremely long-lived in the absence of hosts, surviving desiccation and extreme temperatures in a quiescent state (89). Furthermore, dormant cysts can detect the presence of a host with considerable precision (72). Together, these features make the probability of movement into currently uninfested potato-growing areas and finding hosts extremely likely in the absence of any mitigation measures.

Rate of spread. The rate of spread was formalized in a model based on reaction diffusion (29). Originally developed for spread of mutant genotypes, this form of model has now been expanded for more general use $(9,81)$. They have been shown to approximate the spread of a diverse range of organisms $(23,35,40,46$, 56,68). The models have the general form:

$$
\frac{d n}{d t}=f(n)+D\left(\frac{\partial^{2} n}{\partial x^{2}}+\frac{\partial^{2} n}{\partial y^{2}}\right)
$$

where $f(n)=$ the population growth function, and $D=$ diffusion coefficient.

A generic result of these models is that a population diffusing from a point source will eventually reach a constant asymptotic radial spread rate of $2 \sqrt{ } r D$ in all directions, where $r$ is the population's intrinsic rate of growth $(16,92)$. Hence, the expansion of the area infested by G. rostochiensis was predicted by the function

$$
A_{t}=4 D \pi r t^{2}
$$

where $A_{t}=$ area occupied at time $t, D=$ population diffusion coefficient, and $r=$ the intrinsic rate of population growth $(41,53,79)$. The suitable habitat for $G$. rostochiensis was assumed to be homogenous and expansion rate was equal in every direction.

Equation 3 allowed prediction of the spread on the basis of an estimated intrinsic rate of population growth, while an estimate of $D$ can be derived from the mean dispersal distance (MDD) $(2,17,92)$ :

$$
D=\frac{2 M D D^{2}}{\pi}
$$

However, area alone is insufficient for generating an economic impact assessment because the abundance of $G$. rostochiensis influences the control measures required to counter the lost production. Therefore, the model also assumes that, in each unit of area occupied by the expanding population, the local population density $(N)$ grows following a logistic function until the carrying capacity of the environment $(K)$ is reached $(17,18)$ :

$$
N=\frac{K}{1+\left(\frac{K}{N_{\min }}-1\right) e^{-r t}}
$$

Here, $N_{\min }$ is the size of the original influx. This is assumed to

\begin{tabular}{|c|c|c|c|c|c|}
\hline \multirow[b]{2}{*}{ Symbol } & \multirow[b]{2}{*}{ Parameter } & \multicolumn{3}{|c|}{ Value } & \multirow[b]{2}{*}{ Distribution $^{\mathrm{a}}$} \\
\hline & & Minimum & Mean or mode & Maximum & \\
\hline $\mathrm{Pe}$ & Probability of entry & 0.7 & 0.85 & 1.0 & Uniform \\
\hline$P$ & Probability of establishment & 0.7 & 0.85 & 1.0 & Uniform \\
\hline$A_{\max }(\mathrm{ha})$ & Maximum area of infestation & 38,000 & 38,000 & 38,000 & Invariant \\
\hline$R(\%)$ & Annual population increase & 400 & 1,300 & 8,000 & PERT \\
\hline$N_{\min }$ & Minimum population size & 200 & 500 & $2.3 \times 10^{5}$ & PERT \\
\hline$\mu(\%)$ & Rate of satellite population formation & 0.01 & 0.1 & 1 & Uniform \\
\hline$M D D\left(\mathrm{~km} \mathrm{year}^{-1}\right)$ & Mean dispersal distance & 0.002 & 5 & 50 & PERT \\
\hline
\end{tabular}
have a value of one.

In addition to the expansion of an original outbreak site, it is necessary to incorporate satellite populations. As the area in-

TABLE 1. Biological parameters in model

a PERT = Program Evaluation and Review Technique, used to form a special case of the $\beta$ distribution from minimum, modal and maximum parameters (88). 
volved in an initial site expansion (and the population density within that area) increases, so too does the likelihood of a random event which takes G. rostochiensis to a new site where expansion can once again take place some distance from the original site:

$$
P_{\text {sat }}=\mu A
$$

Here, $\mu$ is the rate of satellite generation and $A$ is the occupied area. Once a satellite site is established, the $G$. rostochiensis population begins to grow and expand in the same manner as the original population. Total occupied area of the original site and satellites grows until $A=A_{\max }$ (maximum habitable area), at which point total area remains constant (92). This point is often referred to as the "carrying capacity" of the environment.

The MDD was estimated from the observed rate of spread in Victoria: from the initial detection at Wandin in 1991 to the most recent detections at Thorpdale in 2008 is a distance of $\approx 85 \mathrm{~km}$ over 17 years, or an average of $\approx 5 \mathrm{~km} /$ year (34) (Victorian Department of Primary Industries, personal communication). Spread from the initial detection to another outbreak at Kooweerup in 2003 was at a similar rate $(47 \mathrm{~km}$ in 12 years or an average of $4 \mathrm{~km} /$ year). This is remarkably similar to the values observed in some other countries (e.g., Slovenia: $132 \mathrm{~km}$ in 33 years or $4 \mathrm{~km} /$ year) (80). This is regarded as the modal distance. The minimum distance is the rate of dispersal of migratory secondstage juveniles through the soil (89). The maximum dispersal distance is the distance between outbreaks, assuming the movement has been in a single "jump" rather than equal yearly increments.

In the absence of any data on local population biology, the rate of population increase was taken from results of field trials and pot experiments conducted outside in various locations. Values were 15 to 40 on the New Zealand south island (54), which is the geographically closest location at which tests have been conducted. Values were 4 to 20 on the New Zealand north island (31). In Western Australia, values were 6 to 13 (84). (Western Australia is geographically farther from Victoria than New Zealand.) These values compare with ranges of 10 to 50 in Bolivia and Ecuador (33), 8 to 39 in Chile (33), 10 to 35 in New York State $(13,51)$, and 3 to 158 in Europe $(20,75,78)$. Rates of multiplication may be dependent on temperature, soil type, virulence of the nematode population, and initial abundance $(20,30)$; however, these factors were not included in the model because they are not yet known for the Victorian population of $G$. rostochiensis.

The minimum area of infestation was taken to be one cyst of $\approx 0.5 \mathrm{~mm}$ in diameter (25). Modal area for a new infestation was estimated at $1 \mathrm{~cm}^{2}$, the size of a small clump of infested soil. Maximum area of new infestation was estimated at $6 \mathrm{~m}^{2}$, the minimum area of an undetected focus of infection under the current testing regime (7).

The smallest potential area of infestation was the area of potato growing in the regions where $G$. rostochiensis has been found (Thorpdale, Kooweerup, and Gembrook: $\approx 1,000$ ha). The maximum potential area of infestation was the area of potato growing in Australia, which has remained stable at $\approx 38,000$ ha for the last 30 years (4).

The minimum initial population was assumed to be one juvenile. Modal value was one cyst containing 500 juveniles (89). This is the number expected in cysts where the abundance of cysts is very low (89). The maximum for an initial population was 1,000 cysts containing an average of 230 juveniles each, the total number of cysts in one undetected focus (7).

Maximum abundance which could be attained in a field was estimated at between an equivalent of $2 \mathrm{eggs} / \mathrm{g}$ of soil (the maximum recorded to date in Victoria) and 1,000 eggs/g of soil (the maximum population recorded in the field) $(67,78,96)$. The modal maximum value used was $240 \mathrm{eggs} / \mathrm{g}$ of soil (78). This is between earlier values of $200 \mathrm{eggs} / \mathrm{g}$ of soil $(11,49)$ and $300 \mathrm{eggs} / \mathrm{g}$ of soil (14).
The relationship between lost crop production and abundance of $G$. rostochiensis has been modeled extensively $(11,24,71$, 77,88 ) but these models have not always accorded perfectly with field data $(33,37,57)$. At low abundances, $G$. rostochiensis causes no decrease in production; therefore the minimum loss was regarded as zero, with no variance. The maximum loss of production has ranged from $60 \%$ (76) to $97 \%$ (11). The modal value used was $75 \%$, which was the modal yield loss at maximum nematode abundance from the highly variable relationships between yield loss and nematode abundance reported $(58-63,90)$.

Average total cost increments. Likely cost increments from the possible presence of $G$. rostochiensis include costs of preplant testing, chemical treatment to minimize crop losses, regulation, certification for export, and loss of export markets.

Preplant testing for $G$. rostochiensis was priced at the current rate charged by the local testing authority ( $\$ 44 /$ ha for taking samples, $\$ 51.5 /$ ha for laboratory determination; Victorian Department of Primary Industries personal communication). Post-entry testing was assumed to be necessary across all potato-growing areas as well as that proportion of the tomato industry geared to exports (i.e., $\approx 5 \%$ of the total industry). No chemical treatments were assumed to take place in the cut-flower industry.

Testing was assumed to be $95 \%$ efficient (7). For the negative tests, it was assumed that no nematicide was applied and crop losses followed the relationships described above. For the positive tests, nematicide was assumed to be applied, with the costs outlined below.

Cost of chemical treatments to minimize crop losses in potato and tomato were based on the current Australian equivalent registered chemicals to the nematicide recommendations for Europe (granular nematicide plus fumigant) $(28,75,93)$. (There are no nematicides registered or recommended for potato in Australia at present.) The chemicals were Metham-sodium (500 liters/ha: \$725) and fenamiphos (24 liters/ha: \$1,130) (21). These are the chemicals registered for use in vegetable crops in Australia. A uniform distribution was used to specify chemical costs with these products forming the minimum and maximum values. Costs of application were calculated at $\$ 40 / \mathrm{ha} /$ spray, including vehicle, equipment, and labor costs of $\approx \$ 35 / \mathrm{h}$ (labor $=\$ 20 / \mathrm{h}$, tractor and spray rig costs [i.e., fuel, oil, maintenance] $=\$ 20 / \mathrm{h}$, time per hectare sprayed $=1 \mathrm{~h} / \mathrm{ha}$ ). This does not include the possibility of tank mixing or dual-purpose spraying and, therefore, may overstate per-unit costs of control (15). Two applications were assumed (i.e., one application of each chemical). In total, these costs are less than those in the United Kingdom for fumigation $(\$ 1,375)$, but similar for granular nematicide $(\$ 1,000)(28)$.

The environmental and social costs of using these chemicals were not included in the model, but may be substantial $(28,93)$.

Despite the application of nematicides, a yield loss may still result. In potato, the extent of this loss was calculated as having a minimum of $0 \%$, a maximum of $30 \%$, and a most-likely value of $15 \%$ per year (47). In tomato crops, the minimum, maximum, and most-likely yield losses despite control were assumed to be 0,10 , and $5 \%$, respectively (15).

The costs of regulation, largely by government agencies, were not included in the model. Also not included were costs associated with developing and deploying resistant cultivars of potato, crop rotations, and other research programs (trap cropping, biocontrol, and so on).

Certification for export was calculated as being the same cost as preplant testing, because current Australian regulations require similar procedures. The costs of documentation and accreditation of certification schemes would be additional to these costs but were not included in the model because they are uncertain and will probably be small relative to the other costs.

Significant export losses may result from $G$. rostochiensis becoming naturalized in Australia, particularly the loss of pestfreedom status, resulting in prohibition of exports. Potato exports 
were worth \$21.6 million in $2002(1,6)$. Many destinations for Australian exported potato tubers are largely free of PCN and may prohibit imports, including Mauritius, Singapore, Malaysia, and Indonesia, collectively accounting for $36 \%$ of Australia's exported potato (1): this was regarded as the modal loss. In addition to loss of area-freedom status, any increased chemical usage may also impede market access, particularly with respect to new and emerging markets (such as those in Europe). Maximum export losses were estimated at $90 \%$, the proportion of 2003 exports that were to countries free of $G$. rostochiensis $(1,6)$. Minimum export loss was assumed to be $0 \%$. A distribution was fitted using these parameters and the same technique as for biological data (Table 1).

Also affected may be export of any crops which are potential hosts of $G$. rostochiensis (tomato and eggplant or aubergine), as well as any crops grown in soils potentially containing $G$. rostochiensis. Tomato plants are mostly grown in different districts

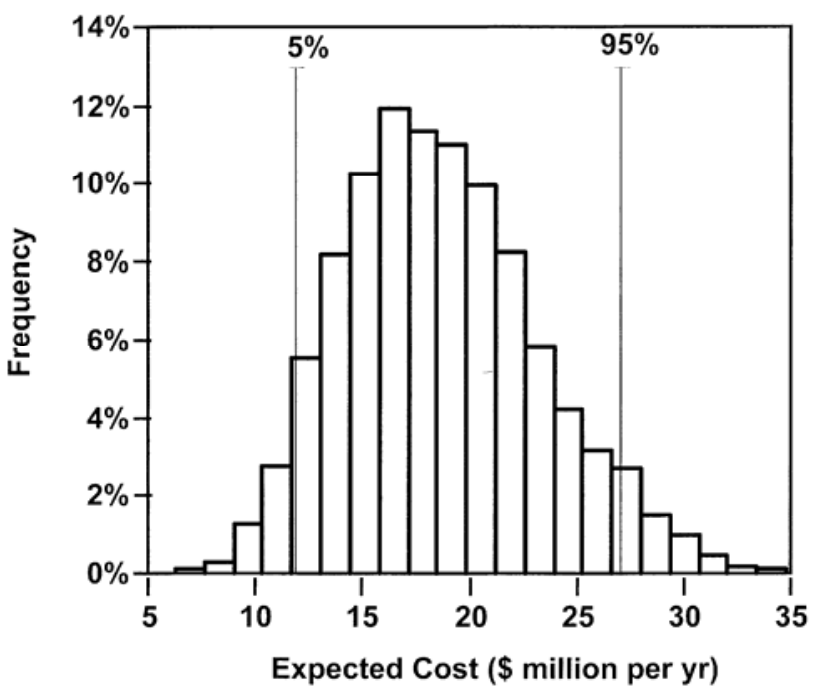

Fig. 1. Histogram of mean annual costs over 20 years associated with Globodera rostochiensis in the absence of measures to eradicate or limit spread. Mean $=\$ 18.7$ million, lower $5 \%$ confidence limit $=\$ 11.9$ million, upper $5 \%$ confidence limit $=\$ 27.0$ million. from potato, but exports may be affected if G. rostochiensis were present and unrestricted in Australia. A minimum of $0 \%$ loss and a maximum of $100 \%$ of fresh tomato export loss was assumed. The value of this crop was $\$ 7$ million in 2004-05 (3). In addition, any crop exports which may deliberately or inadvertently move soil may be affected, such as nursery plants, ornamentals, and cut flowers, worth an estimated $\$ 25$ to 55 million per annum $(5,32$, 36,87 ). A minimum of $0 \%$ and maximum of $100 \%$ of this trade may be affected. We assumed a conservative value of $\$ 25$ million per annum and a modal value of $20 \%$ of exports affected. Intensive chemical treatment to ensure freedom from $G$. rostochiensis is expected to have a detrimental impact on the quality of ornamentals exported, and the significant cost of these chemicals may force many domestic producers out of the world market (15). Reliable statistics on eggplant and aubergine production in Australia prevent their inclusion in the assessment.

Export revenue may also decline as some trading partners prohibit Australian imports because of nematicide use, forcing exporters to seek less lucrative markets. This has not been included in the model.

\section{RESULTS}

The mean annual cost over 20 years of $G$. rostochiensis to Australia was $\$ 18.7$ million, with a range of $\$ 11.9$ to $\$ 27.0$ million per annum (Fig. 1). Over the course of the 20 years simulated by the model, the mean cost was low but rising steadily for the first 2 to 3 years, then increased more rapidly to a peak value of $\approx \$ 23.8$ million at 10 years, before declining slightly (Fig. 2 ). The decline in later years is the result of discounting.

\section{DISCUSSION}

The likely costs of $G$. rostochiensis, should it be allowed to spread freely, may be substantial under most scenarios within the parameters used herein. The $90 \%$ confidence interval for costs represents 2.3 to $5.4 \%$ of the annual return of $\approx$ AUD $\$ 500$ million from the Australian potato industry and 1 to $4 \%$ of the combined gross value of production for the potato, tomato, and cut-flower industries combined.

The results imply that containment or eradication of $G$. rostochiensis can cost a considerable amount before the benefits

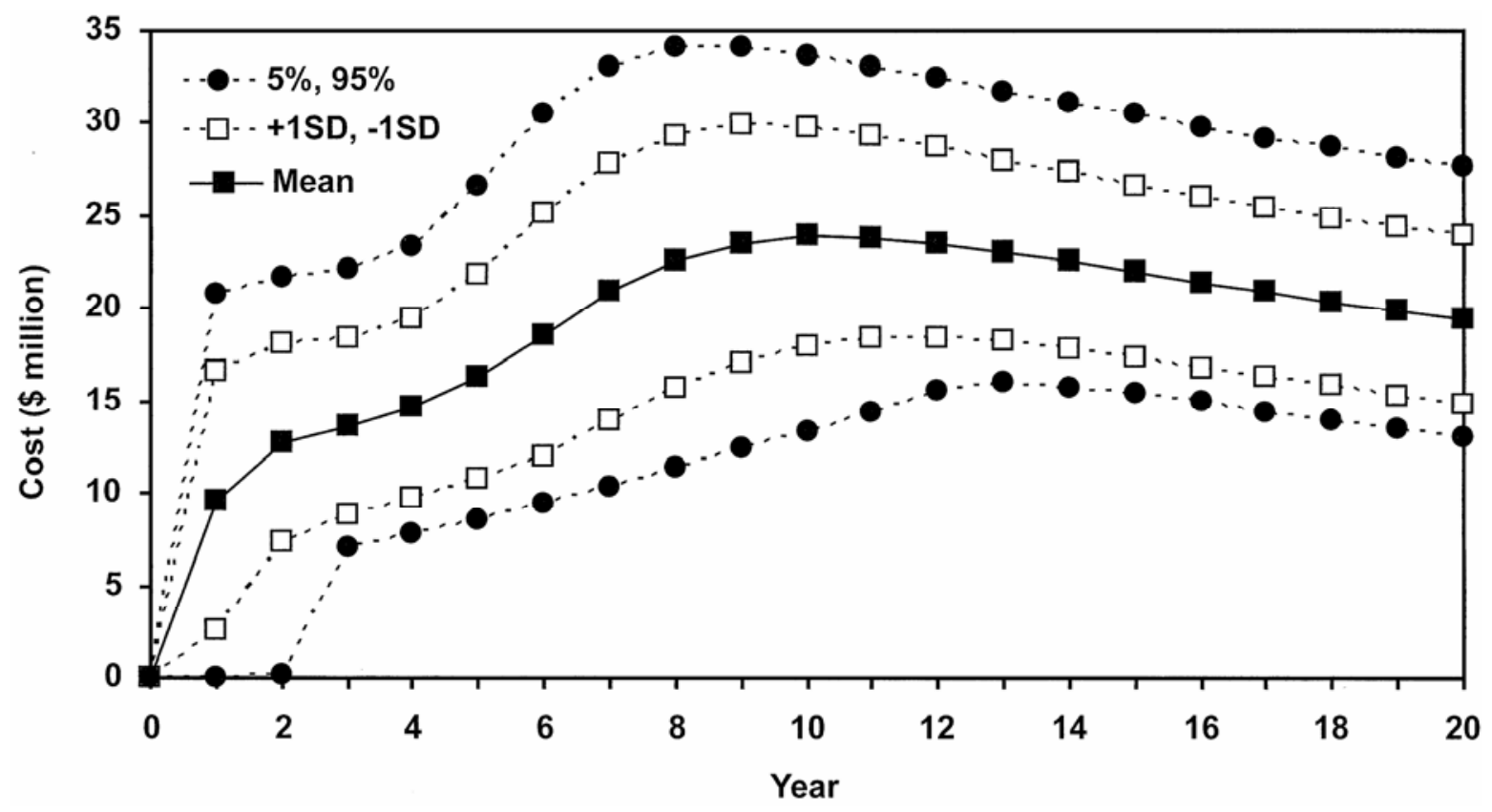

Fig. 2. Expected annual cost for the first 20 years with Globodera rostochiensis in the absence of measures to eradicate or limit spread. 
are completely offset. On average, containment or eradication measures could cost up to $\$ 18.7$ million per annum in real or present-value terms before the ratio of market benefits to costs becomes $<1$. If we consider the upper $5 \%$ confidence limit in Figure 1, the cost of these measures may be justified up to $\$ 27.0$ million per year before affected industries will receive a net loss from control. This illustrates the severity in dollar terms of $G$. rostochiensis as an invasive species.

In the absence of any control measures, there is an initial rapid increase in costs. This is associated with the necessity of testing for PCN. With PCN uncontrolled in Australia, tests or certification of PCN-free status will be required for many export crops (52). In addition, increased testing for PCN by domestic potato producers may occur, as is the norm in Europe (91).

A peak for costs under the model occurs at 8 to 13 years into the future (Fig. 2). After this peak, the cost declines slowly because of the influence of the discounting factor. The use of discounting factors in economic predictions and decisions is the subject of much discussion currently with little resolution (69). This applies particularly in questions comparing immediate or short-term options with longer-term possibilities, when discounting may result in bias toward shorter-term options (69). Thus, the various arguments for the level of discounting should be considered when deciding on the reality of the decline in costs toward year 20 in the model. The costs in these later years may be underestimates.

There is a wide variance in the costs associated with free spread of $G$. rostochiensis up to the peak. This variance appears to be associated with the influence of random events on spread, which is highly variable. There are no estimates of how G. rostochiensis populations behave under Australian conditions to improve the model in this respect. This is evident in the range of MDDs used in the model, ranging from $2 \mathrm{~m}$ (the maximum distance dispersing juveniles may move freely through the soil) to $50 \mathrm{~km}$ per year (the largest "jump" in recorded distribution, undoubtedly assisted). The variance decreases after the peak as the influence of spread becomes less because all available habitat is infested under most possible combinations of parameters.

The main costs once $G$. rostochiensis becomes widespread are crop testing, nematicides, crop losses, and loss of exports. It is entirely possible that all these costs will rise substantially in real terms over time and the costs become greater rather than less. A variety of influences, including certification costs, health concerns, and restrictive trade policies, may be involved. If these costs do increase in real terms, then the model predictions will be an underestimate.

Over 20 years, the vast majority of possible scenarios for $G$. rostochiensis result in cumulative losses in excess of $\$ 370$ million. This is substantially more than the costs of many eradication or control programs, including grower compensation $(70,95)$.

For managing PCN incursions, there are a range of options. The options range from eradication programs such as that being carried out in the United States, through testing and regulation of varying severity and cost to stop or slow spread, to managing PCN for minimization of damage. The option of managing PCN may involve development and deployment of traditionally bred or genetically modified resistant cultivars, trap cropping, or biological control. With any option to manage PCN, a great deal of testing will be required, and this is a major component of the costs of PCN. Therefore, serious attempts to eradicate or control are likely to be most economically attractive in the long term. Conversely, improving cost and efficiency of testing is likely to be economically beneficial under most options.

Many countries other than Australia face similar issues in dealing with PCN. The Australian potato industry (US $\$ 400$ million) is small by comparison with many of these countries; for example, the United States (US\$3.2 billion) and Canada (US\$1.0 billion) (64). In these and other large potato producers such as India,
Turkey, Japan, South Africa, and Indonesia, the costs of an incursion allowed to spread uncontrolled would almost certainly be even greater than that presented here for Australia. Therefore, the potential economic benefits of eradication or control program may be even greater in these countries.

The general form of the cost curve may be similar in countries with strong regulatory regimes and access to chemical treatments for PCN, with an early increase in costs associated with testing, then further increases in spread up to a peak where discounting factors become important. In other countries, the costs from crop losses as PCN spreads may dominate, and the trajectory of costs over time may be different. Whatever the trajectory, it is clear that invasion by PCN can have substantial costs in the long term.

\section{ACKNOWLEDGMENTS}

We thank A. Sheppard (CSIRO Entomology, Canberra, Australia) for discussions about the value of economic analyses and A. LericheGuichard (CSIRO Entomology) for comments on the manuscript.

\section{LITERATURE CITED}

1. Agwest Trade and Development. 2003. AGTRADE Database. Government of Western Australia-Department of Agriculture, South Perth, Australia.

2. Ashton, D. 2007. Australian vegetable growing industry: an economic survey 2005-06. In: ABARE Research Report 07.17. Australian Vegetable Industry Development Group, Canberra, Australia.

3. Australian Bureau of Agricultural and Resource Economics, Ministry of Agriculture and Food. 2006. Agricultural economies of Australia and New Zealand: past, present and future. Australian Bureau of Agricultural and Resource Economics, Canberra, Australia.

4. Andow, D. A., Kareiva, P., Levin, S. A., and Okubo, A. 1990. Spread of invading organisms. Landscape Ecol. 4:177-188.

5. Australian Bureau of Statistics. 2004. AgStats Integrated Regional Database, Catalogue No. 1353.0. Australian Bureau of Statistics, Canberra, Australia.

6. Australian Bureau of Statistics. 2008. Year Book Australia 2008. ABS publication 1301.0. Australian Bureau of Statistics, Canberra, Australia.

7. Been, T. H., and Schomaker C. H. 1996. A new sampling method for the detection of low population densities of potato cyst nematodes (Globodera pallida and G. rostochiensis). Crop Prot. 15:375-382.

8. Biosecurity Australia. 2001. Guidelines for Import Risk Analysis. Agriculture, Fisheries and Forestry Australia/Biosecurity Australia, Canberra, Australia.

9. Britton, N. F. 1986. Reaction-Diffusion Equations and Their Applications to Biology. Academic Press, London.

10. Brodie, B. B., Evans, K., and Franco, J. 1993. Nematode parasites of potatoes. Pages 87-132 in: Plant Parasitic Nematodes in Temperate Agriculture. K. Evans, D. L. Trudgill, and J. M. Webster eds. CAB International, Wallingford, UK.

11. Brown, E. B., and Sykes, G. B. 1983. Assessment of the losses caused to potatoes by the potato cyst nematodes, Globodera rostochiensis and Globodera pallida. Ann. Appl. Biol. 103:271-276.

12. CABI/EPPO. 2002. Crop Protection Compendium-Global Module. CAB International, Cayman Islands.

13. Chitwood, B. G., and Feldmesser, J. 1948. Golden nematode population studies. Proc. Helminthol. Soc. Wash. 15:43-55.

14. Cole, C. S., and Howard, H. W. 1962. Further results from a field experiment on the effect of growing resistant potatoes on a potato root eelworm (Heterodera rostochiensis) population. Nematologica 7:57-61.

15. Cook, D. C. 2003. Prioritising Exotic Pest Threats to Western Australian Plant Industries. Government of Western Australia-Department of Agriculture, Bunbury, WA, Australia.

16. Cook, D. C. 2008. Benefit cost analysis of an import access request. Food Policy 33:277-285.

17. Cook, D. C., and Matheson, A. C. 2008. An estimate of the potential economic impact of pine pitch canker in Australia. Aust. For. 71:107-112.

18. Cook, D. C., Thomas, M. B., Cunningham, S. A., Anderson, D. L., and DeBarro, P. J. 2007. Predicting the economic impact of an invasive species on an ecosystem service. Ecol. Appl. 17:1832-1840.

19. Davis, E., McNeal, D., El-Lissy, O., Berger, P., and Bulluck R. 2007. Current situation of potato cyst nematodes in Idaho. Phytopathology (Abstr.) 97:S151.

20. Den Ouden, H. 1974. The multiplication of three pathotypes of the potato root eelworm on different potato varieties. Neth. J. Plant Pathol. 80:1-6. 
21. Department of Agriculture Western Australia. 2002. Farm Weekly 'Farm Budget Guide' 2002. Government of Western Australia-Department of Agriculture/Farm Weekly, Perth, WA, Australia.

22. Department of Finance Australia. 1991. Handbook of Cost-Benefit Analysis. Australian Government Publishing Service, Canberra, Australia.

23. Dwyer, G. 1992. On the spatial spread of insect pathogens-theory and experiment. Ecology 73:479-494.

24. Elliott, M. J., Trudgill, D. L., McNicol, J. W., and Phillips, M. S. 2004. Projecting PCN population changes and potato yields in infested soils. Pages 143-152 in: Decision Support Systems in Potato Production: Bringing Models to Practice. D. K. L. MacKerron and A. J. Haverkort, eds. Wageningen Academic Publishers, Wageningen, The Netherlands.

25. European Plant Protection Organisation. 1981. Data sheets on quarantine organisms No. 125, Globodera rostochiensis. EPPO Bull. 11:1-5.

26. European Union. 2007. Council Directive 2007/33/EC of 11 June 2007 on the control of potato cyst nematodes and repealing Directive 69/465/EEC. European Union, Brussels.

27. Evans, K., and Kerry, B. 2007. Changing priorities in the management of potato cyst nematodes. Outlooks Pest Manage. 18:265-269.

28. Evans, K., Webster, R., Barker, A., Halford, P., and Russel, M. 2003. Mapping infestations of potato cyst nematodes and the potential for spatially varying application of nematicides. Precis. Agric. 4:149-162.

29. Fisher, R.A. 1937. The wave of advance of advantageous genes. Ann. Eugenics 7:353-369.

30. Foot, M. 1978. Temperature responses of 3 potato-cyst nematode populations from New Zealand. Nematologica 24:412-417.

31. Foot, M. 1978. The ecology of Globodera pallida (Stone) Mulvey \& Stone (Nematoda: Heteroderidae) at Pukekohe, New Zealand. Ph.D. thesis, University of Auckland, Auckland, New Zealand.

32. Foster, M., Jahan, N., and Smith, P. 2005. Emerging Animal and Plant Industries-Their Value to Australia. Rural Industries Research and Development Corporation, Canberra, Australia.

33. Franco, J., Oros, R., Main, G., and Ortuno, N. 1998. Potato cyst nematodes (Globodera species) in South America. Pages 239-269 in: Potato Cyst Nematodes, Biology, Distribution and Control. R. J. Marks and B. B. Brodie, eds. CAB International, Wallingford, UK.

34. Gardner, R., Beardsell, D., Nambiar, L., and Partington, D. 2006. Efficacy of washing to remove cysts of Globodera rostochiensis from potato cv. Trent tubers from peaty clay soil. Australas. Plant Pathol. 35:385-389.

35. Gilligan, C. A. 1995. Modelling soil-borne pathogens: reaction-diffusion models. Can. J. Plant Pathol. 17:96-108.

36. Gollnow, B. 2003. Commercial flower growing in NSW-an industry snapshot. NSW Department of Primary Industries, Sydney, Australia.

37. Greco, N., and Moreno, I. 1992. Influence of Globodera rostochiensis on yield of summer, winter and spring sown potato in Chile. Nematropica 22:165-173.

38. Guy, G. L., Woodward, J., and Hinch, J. L. 1992. Globodera rostochiensis and possibly G. pallida in Australia. J. Nematol. 24:594

39. Hafez, S. L., and Sundararaj, P. 2007. First report of the pale cyst nematode, Globodera pallida, in the United States. Plant Dis. 91:325.

40. Hastings, A., Cuddington, K., Davies, K. F., Dugaw, C. J., Elmendorf, S., Freestone, A., Harrison, S., Holland, M., Lambrinos, J., Malvadkar, U., Melbourne, B. A., Moore, K., Taylor, C., and Thomson, D. 2005. The spatial spread of invasions: new developments in theory and evidence. Ecol. Lett. 8:91-101.

41. Hengeweld, R. 1989. The Dynamics of Biological Invasions. Chapman and Hall, London.

42. Hinchy, M. D., and Fisher, B. S. 1991. A Cost-Benefit Analysis of Quarantine. Australian Bureau of Agricultural and Resource Economics, Canberra, Australia.

43. Hodda, M. 2009. PCN in Australia: myths from the past and narratives for the future. Australas. Nematol. Newsl. 20:11-13.

44. Holland, S. 1981. Potato cyst nematode in Victoria. AQIS Bull. 3:5.

45. Holland, S. 1981. Outbreaks and new records. Australia. Potato cyst nematode, Globodera rostochiensis, in Victoria State. FAO Plant Prot. Bull. 39:113-114.

46. Holmes, E. E. 1993. Are diffusion-models too simple-a comparison with telegraph models of invasion. Am. Nat. 142:779-795.

47. Horticultural Policy Council of Australia. 1993. Potato Cyst Nematode: Impact on Australian Horticulture and a Proposed National Strategy. Industry Report 6, Horticultural Policy Council, Canberra, Australia.

48. Horticulture Research and Development Commission (Australia). 1997. Research Report 1996/97-Vegetables and Other Crops. Horticulture Research and Development Commission, Gordon, NSW, Australia.

49. Huijsman, C. A., Klinkenberg, C. H., and Den Ouden, H. 1969. Tolerance to Heterodera rostochiensis Woll. among potato varieties and its relation to certain characteristics of root anatomy. Eur. Potato J. 12:134-147.

50. Indarti, S., Bambang, R. T. P., Mulyadi, and Triman, B. 2004. First record of potato cyst nematode Globodera rostochiensis in Indonesia. Australas. Plant Pathol. 33:325-326.
51. Lamondia, J. A., and Brodie, B. B. 1986. Effects of initial nematode density on population dynamics of Globodera rostochiensis on resistant and susceptible potatoes. J. Nematol. 18:159-165.

52. Lehman, P. S. 2004. Cost-benefits of nematode management through regulatory programs. Pages 1133-1177 in: Nematology: Advances and Perspectives. Volume 2: Nematode Management and Utilization. Z. X. Chen, S. Y. Chen, and D. W. Dickson, eds. CAB International, Wallingford, UK.

53. Lewis, M. A. 1997. Variability, patchiness, and jump dispersal in the spread of an invading population. Pages 46-74 in: Spatial Ecology: The Role of Space in Population Dynamics and Interspecific Interactions. D. Tilman and P. Kareiva, eds. Princeton University Press, Princeton, NJ.

54. Marshall, J. W. 1984. Comparative biology of Globodera rostochiensis and G. pallida in the South Island of New Zealand. Ph.D. thesis, University of Canterbury, Christchurch, NZ

55. Marshall, J. W. 1998. Potato cyst nematodes (Globodera species) in New Zealand and Australia. Pages 353-394 in: Potato Cyst Nematodes, Biology, Distribution and Control. R. J. Marks and B. B. Brodie, eds. $\mathrm{CAB}$ International, Wallingford, UK.

56. McCann, K., Hastings, A., Harrison, S., and Wilson, W. 2000. Population outbreaks in a discrete world. Theor. Popul. Biol. 57:97-108.

57. Moreno, I., Vovlas, N., and Lamberti, F. 1984. Species of potato cyst nematodes from Chile. Nematol. Mediterr. 12:247-252.

58. Mulder, A. 1997. Effects of soil characteristics on the relationship between potato cyst nematodes and yield. I. Water retention. Potato Res. 40:367-374.

59. Mulder, A., and Van der Wal, A. F. 1997. Relationship between potato cyst nematodes and their principal host. I. A literature review. Potato Res. 40:317-326.

60. Mulder, A., Van der Wal, A. F., and Velema, R. A. J. 1997. Relationship between potato cyst nematodes and their principal host. II. Evaluation of mathematical descriptors relating potato yield and nematode density. Potato Res. 40:327-334.

61. Mulder, A., Van der Wal, A. F., and Velema, R. A. J. 1997. Relationship between potato cyst nematodes and their principal host. III. Consistency and accuracy of nematode density-yield descriptors as influenced by seasonal variation. Potato Res. 40:335-344.

62. Mulder, A., Van der Wal, A. F., and Velema, R. A. J. 1997. Effects of soil characteristics on the relationship between potato cyst nematodes and yield. I. Water retention. Potato Res. 40:367-374.

63. Mulder, A., Van der Wal, A. F., Velema, R. A. J., and Roosjen, J. S. 1997d. Effects of soil characteristics on the relationship between potato cyst nematodes and yield. II. Acidity (soil pH). Potato Res. 40:375-381.

64. National Agricultural Statistics Service (US). 2009. United States and Canadian Potatoes. Agricultural Statistics Board-USDA, Washington, DC.

65. Nikitin, V. S. 1969. On detection of the potato cyst nematode. Zasch. Rast. (Moscow) 8:8.

66. Nikitin, V. S. 1972. Demonstration of loci of the potato cyst eelworm in the Ukraine. Pages 87-88 in: Nematodnye bolezni sel'skokhozyaistvennykh kul'tur i mery bor'by s nimi. Tezisy soveshchaniya. Anonymous, ed. Moscow.

67. Okubo, A., and Levin, S. A. 2002. Diffusion and Ecological Problems: Modern Perspectives, 2nd ed. Springer, New York.

68. Oostenbrink, M. 1961. Nematodes in relation to plant growth. II. The influence of the crop on the nematode population. Neth. J. Agric. Sci. 9:55-60.

69. Pannell, D. J., and Schilizzi, S. G. M., eds. 2006. Economics and the Future: Time and Discounting in Private and Public Decision Making. Edward Elgar, Northampton, MA.

70. Patterson, P. A. 2006. Potato Cyst Nematode Eradication Grower Compensation Program. University of Idaho, Moscow.

71. Perry, J. N. 1983. Effects of spatial heterogeneity on Jones' model for cyst-nematode population dynamics and crop root damage. J. Appl. Ecol. 20:849-856

72. Perry, R. 1998. The physiology and sensory perception of potato cyst nematodes, Globodera species. Pages 27-49 in: Potato Cyst Nematodes, Biology, Distribution and Control. R. J. Marks and B. B. Brodie, eds. CAB International, Wallingford, UK.

73. Pylypenko, L. A., Uehara, T., Phillips, M. S., Sigareva, D. D., and Blok, V. C. 2005. Identification of Globodera rostochiensis and G. pallida in the Ukraine by PCR. Eur. J. Plant Pathol. 111:39-46.

74. Quader, M., Nambiar, L., and Cunnington, J. 2008. Conventional and real-time PCR-based species identification and diversity of potato cyst nematodes (Globodera spp.) from Victoria, Australia. Nematology 10:471-478.

75. Seinhorst, J. W. 1982. The economics of nematode control by crop-rotation and chemical, soil and plant treatment. Nematologica 28:170-171.

76. Seinhorst, J. W. 1982. The relationship in field experiments between population-density of Globodera rostochiensis before planting potatoes 
and yield of potato-tubers. Nematologica 28:277-284

77. Seinhorst, J. W. 1986. Effects of nematode attack on the growth and yield of crop plants. Pages 191-209 in: Cyst Nematodes. F. Lamberti and C. E. Taylor, eds. Plenum Press, London.

78. Seinhorst, J. W. 1986. Agronomic aspects of potato cyst nematode infestation. Pages 211-227 in: Cyst Nematodes. F. Lamberti and C. E. Taylor, eds. Plenum Press, London.

79. Shigesada, N., and Kawasaki, K. 1997. Biological Invasions: Theory and Practice. Oxford University Press, Oxford.

80. Sirca, S., and Urek, G. 2005. Results of the study of the yellow potato cyst nematode G. rostochiensis Woll. (Behrens) in Slovenia. Pages 349352 in: Lectures and Papers Presented at the 7th Slovenian Conference on Plant Protection. Anonymous, ed. Drustvo za varstvo rastlin Slovenje, Ljubljana, Slovenia.

81. Skellam, J. G. 1951. Random dispersal in theoretical populations. Biometrika 38:196-218.

82. Stanton, J. M. 1986. First record of potato cyst nematode Globodera rostochiensis in Australia. Australas. Plant Pathol. 15:87.

83. Stanton, J. M. 1987. Potato cyst nematode. J. Agric. West. Aust. 28:9-11.

84. Stanton, J. M., and Sartori, M. 1990. Hatching and reproduction of the potato cyst nematode, Globodera rostochiensis, from potato fields in Western Australia as influenced by soil temperature. Nematologica 36:457-464.

85. Stirling, G. R., Stanton, J. M., and Marshall, J. W. 1992. The importance of plant-parasitic nematodes to Australian and New Zealand agriculture. Australas. Plant Pathol. 21:104-115.

86. Sun, F., Miller, S., Wood, S., and Cote, M.-J. 2007. Detection of potato cyst nematode, Globodera rostochiensis, on potato in Saint-Amable region, Québec, Canada. (Abstr.) Phytopathology 97:S152.

87. Sutton, S. 2002. Export flower industry: a review of recorded statistics. Rural Industries Research and Development Corporation, Canberra, Australia.
88. Trudgill, D. L. 1986. Yield losses caused by potato cyst nematodes-a review of the current position in Britain and prospects for improvements. Ann. Appl. Biol. 108:181-198.

89. Turner, S., and Evans, K. 1998. The origins, global distribution and biology of potato cyst nematodes (Globodera rostochiensis (Woll.) and Globodera pallida Stone). Pages 7-26 in: Potato Cyst Nematodes, Biology, Distribution and Control. R. J. Marks and B. B. Brodie, eds. CAB International, Wallingford, UK.

90. Van der Wal, A. F., Mulder, A., and Velema, R. A. J. 1997. Relationship between potato cyst nematodes and their principal host. IV. Tolerance of potato cultivars and the effect of potato cyst nematode on initial plant growth. Potato Res. 40:345-353.

91. Van Riel, H. R., and Mulder, A. 1998. Potato cyst nematodes (Globodera species) in western Europe. Pages 271-298 in: Potato Cyst Nematodes, Biology, Distribution and Control. R. J. Marks and B. B. Brodie, eds. CAB International, Wallingford, UK.

92. Vose, D. 2000. Risk Analysis: A Quantitative Guide. John Wiley \& Sons, Chichester, UK

93. Waage, J. K., Fraser, R. W., Mumford, J. D., Cook, D. C., and Wilby, A. 2005. A New Agenda for Biosecurity. Department for Food, Environment and Rural Affairs, London.

94. Whitehead, A. G., and Turner, S. 1998. Management and regulatory control strategies for potato cyst nematodes (Globodera rostochiensis and Globodera pallida). Pages 135-152 in: Potato Cyst Nematodes, Biology, Distribution and Control. R. J. Marks and B. B. Brodie, eds. CAB International, Wallingford, UK.

95. Woldendorp G., and Bomford M. 2004. Weed Eradication: Strategies, Timeframes and Costs. Bureau of Rural Sciences, Canberra, Australia.

96. Yang, J., Perry, J. N., Evans, K., and Haydock, P. P. J. 2000. Adaption of a population dynamic model for prediction of potato cyst nematode distribution within fields. Asp. Appl. Biol. 59:109-114. 